Check for updates

1 Health Service Journal, London, UK

2 The BMJ, London, UK

Correspondence to: A McLellan alastair.mclellan@hsj.co.uk Cite this as: BMJ 2020;371:m4847 http://dx.doi.org/10.1136/bmj.m4847 Published: 15 December 2020

\section{Covid 19: Christmas relaxation will overwhelm services}

\author{
To protect the NHS, the UK government must abandon plans for household mixing
}

Alastair McLellan, ${ }^{1}$ Fiona Godlee ${ }^{2}$

Since the UK's first lockdown in March, the government has had one (perhaps only one) consistent message-protect the NHS. Now, with the number of hospital patients with covid-19 again on the rise, and a third wave almost inevitable, the New Year is likely to see NHS trusts facing a stark choice: be overwhelmed or stop most elective and non-urgent work. Rather than lifting restrictions over Christmas as currently planned, the UK should follow the more cautious examples of Germany, Italy, and the Netherlands.

By and large the NHS has coped well with the additional caseload from covid-19 patients during the autumn. The second wave began to hit hospitals at the start of September. Government figures report 451 inpatients with covid-19 in England on 2

September. ${ }^{1}$ Over the ensuing 10 weeks, the numbers rose steadily and then rapidly, peaking at a reported 14712 inpatients in England on 23 November. ${ }^{1}$

If the third wave turns out to be of the same order of magnitude as the second wave, the health service should manage. But this will be the case only if the third wave starts with a broadly similar extra caseload of covid-19 inpatients as at the beginning of the second wave: around 450. With current restrictions failing to control the virus, extrapolation suggests that the actual figure is likely to be more than 40 times higher, as we explain below. The planned relaxation of restrictions over Christmas will boost the numbers further as the NHS also struggles with the additional demands of winter.

England went into lockdown on 5 November, and the number of inpatients with covid-19 began to fall, down to 12968 on 5 December. ${ }^{1}$ If this rate of decline had continued, the English NHS would have been on course for just under 11 ooo covid-19 inpatients on 31 December. However, in the past two weeks, despite most of the country being in tiers 2 or 3 of restrictive measures, numbers of inpatients have started to rise again. By 14 December (the latest data available) the covid bed occupancy had climbed back to 15053 . Unless something happens to change this trajectory, hospitals in England will have just short of 19000 patients with covid on New Year's Eve. This figure, derived by extrapolating a straight line from 5 December to 14 December through to 31 December, would be almost exactly the same as the 18974 peak of the first wave on 12 April.

The NHS currently has around 95 ooo general acute beds. It is operating with around $10 \%$ fewer beds than a year ago as a result of infection prevention and control measures introduced to try to stop the spread of covid in hospitals.
The main effect of a further surge in covid-19 inpatients is likely to be felt most by those with other conditions. The NHS has learnt from the first and second waves and has robust plans to rapidly increase intensive care capacity, including through the Nightingale hospitals. But how are these to be staffed? A large influx of patients with covid-19, similar or greater than that seen in the autumn, can only be managed if staff and other resources are diverted from treating non-covid patients. Having recovered much of their capacity for elective and non-urgent care during the autumn, NHS trusts in the most pressured regional health systems are already having to cancel almost all such activity because of the resurgent virus. ${ }^{2} \mathrm{~A}$ substantial third wave could wipe out almost all the reductions in waiting times for elective procedures achieved in the past 20 years. Average waiting times will reach 12 months by March next year. ${ }^{3}$ This will take years to recover from, at the cost of much suffering and loss of life.

The coming months are also likely to see the NHS under intense winter pressures from seasonal outbreaks of norovirus, increased admissions of frail older people, and the peak of staff absence. The NHS will also be in the middle of delivering the largest vaccination programme in its 72 year history, through already overstretched general practices and hospitals. Even if NHS England succeeds in vaccinating all those “at risk" by Easter, this won't be in time to prevent hospital admission and death for many during the next few months. NHS Track and Trace, which in fact has almost nothing to do with the NHS, continues to squander money on failure. ${ }^{4}$ So too does the mass testing of asymptomatic people using lateral flow tests that are not fit for purpose. ${ }^{5}$

London and many neighbouring counties will enter tier 3 on 16 December. However, other areas such as Kent, which has been in tier 3 since 2 December, are still seeing strong increases in hospital admissions. These measures are clearly inadequate.

Ministers are meeting on 16 December to review current restrictions for England. When they devised the current plans to allow household mixing over Christmas they had assumed the covid-19 demand on the NHS would be decreasing. But it is not; it is rising, and the emergence of a new strain of the virus has introduced further potential jeopardy.

Of particular concern is the effect on staff, many of whom have already worked through the hardest nine months of their professional lives. ${ }^{7}$ Levels of burnout and sickness absence are likely to exceed those already experienced. 


\section{What should be done}

Members of the public can and should mitigate the effect of the third wave by being as careful as possible over the next few months. But many will see the lifting of restrictions over Christmas as permission to drop their guard. The government was too slow to introduce restrictions in the spring and again in the autumn.

It should now reverse its rash decision to allow household mixing and instead extend the tiers over the five day Christmas period. In order to bring numbers down in advance of a likely third wave, it should also review and strengthen the tier structure, which has failed to suppress rates of infection and hospital admission.

This joint editorial is only the second in the more than 100 year histories of The BMJ and the Health Service Journal. ${ }^{8}$ We are publishing it because we believe the government is about to blunder into another major error that will cost many lives. If our political leaders fail to take swift and decisive action, they can no longer claim to be protecting the NHS.

A version of this editorial has been simultaneously published in the Health Service Journal and The $B M$.

Competing interests: We have read and understood BMJ policy on declaration of interests and have no relevant interests to declare.

Provenance and peer review: Commissioned; externally peer reviewed.

$1 \quad$ NHS. Covid-19 hospital activity. https://www.england.nhs.uk/statistics/statistical-work-areas/covid19-hospital-activity/

2 Moore A. Four trusts cancel planned operations as covid pressures mount. HS/2020 Dec 8. https://www.hsj.co.uk/coronavirus/four-trusts-cancel-planned-operations-as-covid-pressuresmount/7029119.article

3 Findlat R. Waiting times will probably top 52 weeks by March. HS/2020 Dec 10. https://www.hsj.co.uk/quality-and-performance/waiting-times-will-probably-top-52-weeks-bymarch/7029138.article

4 Wise J. Covid-19: Test and trace system must improve its below par performance, NAO concludes. BMJ2020;371:m4796. doi: 10.1136/bmj.m4796 pmid: 33310777

5 Deeks JJ, Raffle AE. Lateral flow tests cannot rule out SARS-CoV-2 infection. BMJ2020;371:m4787. doi: 10.1136/bmi.m4787 pmid: 33310701

6 Gill M, Gray M. Mass testing for covid-19 in the UK. BMJ2020;371:m4436. doi: 10.1136/bmj.m4436 pmid: 33199289

7 Gerada C, Walker C. Covid-19-will this second phase be harder than the first? BMJ Opinion, 13 May 2020. https://blogs.bmi.com/bmi/2020/05/13/covid-19-will-this-second-phase-be-harderthan-the-first/

8 McLellan A, Middleton J, Godlee F. Lansley’s NHS “reforms”. BMJ 2012;344:e709. doi: 10.1136/bmj.e709 pmid: 22294740

This article is made freely available for use in accordance with BMJ's website terms and conditions for the duration of the covid-19 pandemic or until otherwise determined by BMJ. You may use, download and print the article for any lawful, non-commercial purpose (including text and data mining) provided that all copyright notices and trade marks are retained. 